\title{
Effect of the roughage/concentrate ratio on nitrogen entering the small intestine of dairy cows
}

\section{S. Tamminga}

Institute for Livestock Feeding and Nutrition Research 'Hoorn', Lelystad, Netherlands

Accepted: 20 september 1981

Key-words: digestibility, protein, rumen, site of digestion, microbial protein, dairy cow

\section{Summary}

Experiments were conducted with dairy cows in which the effect of a varying roughage/concentrate ratio on $\mathrm{N}$ entering the small intestine was studied at various levels of feed intake. Experimental animals were equipped with a rumen fistula and re-entrant cannulae at the beginning of the small intestine. In three series a total of 10 treatments were applied with 2 to 5 animals per treatment. Dry matter intake ranged between 3.8 and $15.7 \mathrm{~kg}$ per day; the proportion of long roughage in the diet varied from 0.29 to 0.81 .

The apparent digestibility of organic matter (O), crude fibre (XF) and $\mathrm{N}$ free extracts $(\mathrm{XX})$ was $0.76 \pm 0.007,0.69 \pm 0.027$ and $0.81 \pm 0.012$ respectively. The proportion of the digestion taking place in the stomachs was $0.59 \pm 0.008,0.94 \pm 0.012$ and $0.76 \pm 0.007$ for $\mathrm{O}, \mathrm{XF}$ and $\mathrm{XX}$ respectively. A tendency was found that a larger proportion of the apparently digestible organic matter was digested in the stomachs with a larger proportion of long roughage in the diet.

The contribution of microbial $\mathrm{N}$ to the intestinal $\mathrm{N}$ was estimated, with DAPA as a microbial marker. From this the efficiency of microbial protein synthesis was estimated and related to the amount of carbohydrates (XF + $\mathrm{XX}$ ) fermented in the stomachs. Per kg of carbohydrates fermented $32 \pm 1.5 \mathrm{~g}$ microbial $\mathrm{N}$ were produced. The percentage of dietary $\mathrm{N}$ not degraded in the stomachs was also estimated and averaged $30 \pm 1.5$.

Varying the ratio between long roughage and pelleted concentrates appeared to have little effect on the degradation of dietary protein or on the efficiency of microbial protein synthesis. Hence with a proportion of long roughage in the diet between 0.29 and 0.81 there seems little effect of varying the roughage/concentrate ratio on the protein supply in dairy cows. 


\section{Introduction}

Lactating dairy cows are generally fed with a basal diet of long roughage (meadow hay, grass silage) supplemented with ground and often pelleted concentrates, the amount of which varies with the level of production. At high levels of production it may be necessary to replace part of the roughage by concentrates in order to maximize energy intake. This increase in energy intake is achieved because more dry matter can be ingested from ground feeds (van der Honing, 1975) and because in general the energy density of concentrates is higher than of roughages.

Changing the ratio between long roughage and ground and pelleted concentrates in the diet of dairy cows may change rumen fermentation, including degradation and synthesis of protein, in various ways. Degradation of dietary ingredients depends on the rate of degradation and on the rate of passage of that ingredient through the forestomachs. Rate of passage differs between long hay particles and ground and pelleted concentrates (Hartnell \& Satter, 1979; Uden, 1981). Rate of passage of particular matter is higher with ground and pelleted concentrates. The rate of degradation may also differ. Rate of protein degradation is lower with high concentrate diets (Ganev et al., 1979). Rate of carbohydrate degradation on the other hand is higher with concentrate-rich diets than with roughage-rich diets, which probably influences microbial protein synthesis (Tamminga, 1979).

In a number of experiments it was therefore investigated if the duodenal protein supply in dairy cows was affected by changes in the ratio between long roughage and ground and pelleted concentrates.

\section{Materials and methods}

For the experiments a total of 7 dairy cows were used. All animals were fitted with a rumen fistula according to the method of van 't Klooster \& Rogers (1970). Polythene tubing with an internal diameter of $37 \mathrm{~mm}$, normally applied as waste pipe of a wash bowel (Vulcathene, Eriks, Alkmaar) was used for this purpose. The animals were also fitted with a re-entrant cannula in the beginning of the small intestine, just beyond the pancreatic and biliary duct. Cannulae were of the same type as those used by Ash (1962) in sheep, except that they were made of polyvinyl chloride and had an internal diameter of 19 $\mathrm{mm}$. Cannulation was performed according to the method described by Hogan \& Phillipson (1960) in sheep.

The animals were fed with various amounts of long meadow hay and various amounts of ground and pelleted concentrates. No specific composition was requested for the concentrates, they were bought from a local feed manufacturer.

Three series of experiments were performed. The first series consisted of 3 treatments with 3 animals per treatment. In the second series again 3 experiments were done, but only 2 animals per treatment were available. In the third 
Table 1. Animals and experimental treatments.

\begin{tabular}{llll}
\hline Treatment & \multicolumn{2}{l}{ Diet offered } & Animals \\
\cline { 2 - 3 } & kg hay & kg concentrates \\
I-A & 4 & 10 & $66,78.81$ \\
I-B & 6 & 9 & $66,78,93$ \\
I-Cl & 8 & 8 & 66,78 \\
I-C2 & 6 & 6 & 93 \\
II-A & 3 & 7 & 35,78 \\
II-B & 6 & 4.5 & 35,78 \\
II-C & 9 & 2 & 35,78 \\
III-A & & & \\
III-A2 & 6.5 & 12 & 93 \\
III-B1 & 10 & 10 & 93 \\
III-B2 & 8 & 2 & 78 \\
III-B3 & 8 & 3 & $2 R$ \\
III-B4 & 7 & 1 & 128 \\
III-B5 & 6 & 1 & 35 \\
III-C1 & 3 & 2 & 93 \\
III-C2 & 2.5 & 4 & 78 \\
III-D1 & 4 & 3.5 & 93 \\
III-D2 & 3 & 2 & 35 \\
\hline
\end{tabular}

series of experiments, the animals were fed depending on their stage of lactation, resulting in 11 experiments which were grouped in 4 groups of experiments. A summary of the experiments is given in Table 1 .

Measuring and sampling feed intake, duodenal flow and faecal output

Of each part of the diet (roughage, concentrates) a sample was prepared, while weighing the daily portions for an entire collection period, before the collection of duodenal digesta and faeces started. Feed refusals were collected during an entire measuring period and sampled at the end of each period.

The measuring and sampling procedure of duodenal flow was described in detail by Tamminga et al. (1973). At the start of an experiment the re-entrant cannulae were disconnected. The proximal cannula was fitted to a polyethylene tube, through which the digesta flowed into a container which contents were kept at a constant temperature of $38^{\circ} \mathrm{C}$. From this container amounts of approximately 45 litres were removed and transferred to a sampling bucket. The contents of this bucket were weighed in grammes, and a proportional sample of $1.65 \%$ was taken. The remainder of the digesta was transferred to a second container from where it was gradually pumped upwards by means of a peristaltic pump into a funnel, which was connected with the distal cannula. For each period of 24 hours the small samples were bulked, cooled immediately to $8-10^{\circ} \mathrm{C}$ and kept at that temperature. Preservation of the samples was done with $10 \mathrm{ml}$ of toluene. At the end of each 24-hour period the samples 


\section{S. TAMMINGA}

were split in daily samples and composite samples, frozen and kept at $-20^{\circ} \mathrm{C}$ until freeze-drying or further analysis. Measuring and sampling of the duodenal flow was continued for a period of 96 hours.

During the same period faeces were also collected, immediately after being dropped, thus avoiding contamination with urine. This procedure was chosen because wearing harnesses for a separate collection of faeces and urine was considered less appropriate for such surgically modified animals. The collected faeces were weighed daily and proportional daily samples were bulked. The samples were kept at $4{ }^{\circ} \mathrm{C}$ until the end of the collection period and were then prepared further.

\section{Isolation of mixed rumen bacteria}

Mixed rumen bacteria were isolated according to the method of Meyer et al. (1967). Approximately l litre of ruminal fluid was collected by suction through a $100-\mathrm{ml}$ syringe fitted with a polythene tube which was placed in a stainless steel rod of which the lower end was perforated. The rod was placed in the rumen through the rumen fistula. Rumen fluid was cooled immediately by placing it in ice, and subsequently centrifuged at $550 \mathrm{~g}$ to remove particles and protozoa. The supernatant was subsequently centrifuged at $70000 \mathrm{~g}$. The resulting supernatant was discarded and the residue taken up in buffer, homogenized in a Potter-Elvehjem homogenizer and recentrifuged. This procedure was repeated and finally the suspension was frozen and kept at $-20^{\circ} \mathrm{C}$ until freeze-drying.

\section{Preparation of samples and chemical analysis}

Fresh samples of faeces and duodenal content were analysed for their dry matter content and $\mathrm{N}$ content. Otherwise samples were dried at $60^{\circ} \mathrm{C}$ for 24 hours and ground in an hammermill through a sieve of $1 \mathrm{~mm}$ and this material was used for further analysis. The bulked samples of duodenal digesta were freeze-dried and also ground.

Most analytical procedures were according to the instructions of the Netherlands Normalization Institute (NEN instructions).

Dry matter in air dry samples was determined by drying a small sample (approx. $3 \mathrm{~g}$ ) for a period of 4 hours at 103 to $105^{\circ} \mathrm{C}$ (NEN 3332). Dry matter in wet samples (faeces and duodenal digesta) was determined by drying a small sample (10 to $15 \mathrm{~g}$ for faeces and 20 to $30 \mathrm{~g}$ for duodenal digesta) for 15 hours at 103 to $105^{\circ} \mathrm{C}$. The ash content of air-dry samples was determined by ashing a small sample (approx. $3 \mathrm{~g}$ ) in a furnace at $550^{\circ} \mathrm{C}$ for a period of 3.5 hours (NEN 3329). Crude protein $(\mathrm{N} \times 6.25)$ in part of the samples was determined according to the Kjeldahl method (NEN 3145). In the remaining samples crude protein was determined according to the Dumas method, with an automatic $\mathrm{N}$ analyser (Mikro-rapid-N, Heraeus, W. Germany). Crude fibre in air-dry samples was determined by boiling a small sample (approx. $3 \mathrm{~g}$ ) with an aqueous solution of $1.25 \% \mathrm{H}_{2} \mathrm{SO}_{4}$ for 30 minutes, followed by boiling the residue with an aqueous solution of $1.25 \% \mathrm{NaOH}$ for 30 minutes. The residue was 
washed with acetone, dried at $140^{\circ} \mathrm{C}$ for 2 hours and ashed in a furnace at $550^{\circ} \mathrm{C}$ for 1 hour. The difference in weight after drying and ashing is a measure for the crude fibre content (NEN 3326). Crude fat in air-dry samples was determined by extracting a small sample (approx. $3 \mathrm{~g}$ ) in a Soxhlet apparatus with peroxide-free diethyl ether for 16 hours (NEN 3148). Diaminopimelic acid was determined according to the method of Mason \& Anderson (1976) in which hydrolysis by boiling the sample under reflux for 22 hours with $400 \mathrm{ml}$ of $6 \mathrm{~N} \mathrm{HCl}$ is preceded by oxidation with performic acid.

\section{Results}

The composition of the hay and concentrates fed in the various experiments is shown in Table 2.

In Table 3 the digestion results of Experiment $I$ are shown for dry matter $(T)$, organic matter $(\mathrm{O})$, crude protein (XP), crude fibre (XF) and NfE (XX) in terms of intake $\left(\mathrm{I}_{\mathrm{X}}\right)$, apparently digested $\left(\mathrm{d}_{\mathrm{X}}\right)$ and apparently digested in the stomachs $\left(d_{X, S}\right)$, the latter as a percentage of $d_{x}$.

The proportion of duodenal $\mathrm{N}$ of bacterial origin was estimated with DAPA as a marker. Since carbohydrates are by far the most important energy donating substrate for rumen micro-organisms and since hardly any interfering endogenous carbohydrates are involved, the energetic efficiency of microbial protein synthesis was related to the amount of carbohydrates $(\mathrm{XF}+\mathrm{XX})$ disappeared between intake and duodenal flow (Tamminga, 1978). The results are shown in Table 4. Duodenal flow was corrected for $\mathrm{NH}_{3}-\mathrm{N}$; of the remaining NAN, $15 \%$ was considered to be of endogenous origin (Kaufmann \& Hagemeister, 1976). This corrected duodenal $\mathrm{N}$-flow was considered as the total of microbial $\mathrm{N}$ and undegraded feed- $\mathrm{N}$. The undegraded feed $\mathrm{N}$ was calculated as proportion of the $\mathrm{N}$ ingested and the results are also shown in Table 4.

Table 2. Chemical composition of hay and concentrates fed in the different experiments.

\begin{tabular}{lllllll}
\hline Exp. & Feed & $\% \mathrm{~T}$ & $\mathrm{O} / \mathrm{T}$ & $\mathrm{XP} / \mathrm{T}$ & $\mathrm{XF} / \mathrm{T}$ & $\mathrm{XX} / \mathrm{T}$ \\
I & Hay & 83.2 & 0.900 & 0.177 & 0.303 & 0.396 \\
& Conc. & 85.7 & 0.919 & 0.193 & 0.072 & 0.613 \\
II & Hay & 82.5 & 0.915 & 0.131 & 0.302 & 0.462 \\
& Conc. & 86.2 & 0.933 & 0.190 & 0.070 & 0.631 \\
III-A & Hay & 82.3 & 0.914 & 0.128 & 0.301 & 0.464 \\
& Conc. & 85.9 & 0.931 & 0.193 & 0.053 & 0.628 \\
III-B & Hay & 85.2 & 0.900 & 0.130 & 0.291 & 0.453 \\
& Conc. & 86.0 & 0.916 & 0.168 & 0.084 & 0.627 \\
III-C & Hay & 84.8 & 0.912 & 0.145 & 0.335 & 0.410 \\
& Conc. & 86.0 & 0.930 & 0.195 & 0.090 & 0.601 \\
III-D & Hay & 85.1 & 0.902 & 0.154 & 0.294 & 0.427 \\
& Conc. & 85.3 & 0.924 & 0.204 & 0.082 & 0.595 \\
\hline
\end{tabular}




\section{S. TAMMINGA}

Table 3. Intake $\left(\mathrm{I}_{\mathrm{X}}, \mathrm{kg} / \mathrm{day}\right)$, total apparent digestibility $\left(\mathrm{d}_{\mathrm{X}}, \%\right)$ and apparent digestibility in the forestomachs, as a percentage of $d_{X}\left(d_{X . S}\right)$ in Experiment 1 .

\begin{tabular}{|c|c|c|c|}
\hline & \multicolumn{3}{|l|}{ Treatment* } \\
\hline & I-A (3) & I-B (3) & I-C (3) \\
\hline DM from roughage (\%) & $29 \pm 0.5$ & $40 \pm 0.2$ & $48 \pm 1.3$ \\
\hline $\mathrm{XP}$ from roughage $(\%)$ & $27 \pm 0.4$ & $37 \pm 0.7$ & $46 \pm 0.5$ \\
\hline $\mathrm{I}_{\mathrm{T}}$ & $11.8 \pm 0.18$ & $12.3 \pm 0.51$ & $12.1 \pm 0.96$ \\
\hline $\mathrm{I}_{\mathrm{O}}$ & $10.8 \pm 0.16$ & $11.2 \pm 0.44$ & $11.0 \pm 0.88$ \\
\hline$I_{X P}$ & $2.20 \pm 0.04$ & $2.29 \pm 0.14$ & $2.23 \pm 0.15$ \\
\hline $\mathrm{I}_{\mathrm{XF}}$ & $1.67 \pm 0.04$ & $2.06 \pm 0.11$ & $2.26 \pm 0.14$ \\
\hline $\mathrm{I}_{\mathrm{XX}}$ & $6.45 \pm 0.18$ & $6.45 \pm 0.18$ & $6.15 \pm 0.56$ \\
\hline $\mathrm{d}_{\mathrm{T}}$ & $74 \pm 2.2$ & $75 \pm 1.1$ & $76 \pm 0.9$ \\
\hline $\mathrm{d}_{\mathrm{O}}$ & $76 \pm 2.2$ & $77 \pm 1.1$ & $78 \pm 1.0$ \\
\hline$d_{X P}$ & $70 \pm 4.6$ & $70 \pm 0.3$ & $71 \pm 1.5$ \\
\hline $\mathrm{d}_{\mathrm{XF}}$ & $62 \pm 4.1$ & $69 \pm 2.3$ & $72 \pm 2.0$ \\
\hline$d_{X X}$ & $82 \pm 1.4$ & $83 \pm 1.3$ & $83 \pm 0.7$ \\
\hline $\mathrm{d}_{\mathrm{T} . \mathrm{S}}$ & $44 \pm 1.8$ & $44 \pm 3.4$ & $49 \pm 2.8$ \\
\hline $\mathrm{d}_{\mathrm{O} . \mathrm{S}}$ & $57 \pm 1.7$ & $57 \pm 2.8$ & $62 \pm 2.8$ \\
\hline $\mathrm{d}_{\mathrm{XPS}}$ & $3 \pm 5.5$ & $1 \pm 2.8$ & $10 \pm 7.4$ \\
\hline $\mathrm{d}_{\mathrm{XF} . \mathrm{S}}$ & $90 \pm 0.8$ & $88 \pm 6.8$ & $96 \pm 2.4$ \\
\hline$d_{x x . S}$ & $77 \pm 3.9$ & $74 \pm 2.0$ & $74 \pm 3.5$ \\
\hline
\end{tabular}

* In parenthesis number of animals

Table 4. Efficiency of microbial protein synthesis and extent of degradation of feed $\mathrm{N}$ in Experiment I

\begin{tabular}{llll}
\hline & \multicolumn{2}{l}{ Treatment } & \\
\cline { 2 - 3 } & $\mathrm{I}-\mathrm{A}$ & $\mathrm{I}-\mathrm{B}$ & $\mathrm{I}-\mathrm{C}$ \\
$\begin{array}{l}(\mathrm{XF}+\mathrm{XX}) \text { disappeared } \\
(\mathrm{kg} / \text { day })\end{array}$ & $5.1 \pm 0.19$ & $5.3 \pm 0.30$ & $5.5 \pm 0.46$ \\
$\begin{array}{l}\text { Microbial N in } \\
\text { Duodena! content } \\
(\mathrm{g} / \text { day) }\end{array}$ & $176 \pm 3.2$ & $198 \pm 10.4$ & $150 \pm 19.5$ \\
$\begin{array}{l}\text { Micr. N/(XF }+\mathrm{XX}) \text { ferm. } \\
(\mathrm{g} / \mathrm{kg})\end{array}$ & $34 \pm 1.4$ & $38 \pm 4.3$ & $28 \pm 5.0$ \\
$\begin{array}{l}\text { Undegraded feed } \mathrm{N} \\
\left(\% \text { in } \mathrm{I}_{\mathrm{N}}\right)\end{array}$ & $28 \pm 7.2$ & $24 \pm 2.9$ & $29 \pm 9.4$ \\
\hline
\end{tabular}

In Table 5 the digestion results of Experiment II are shown for dry matter (T), organic matter (O), crude protein (XP), crude fibre (XF) and NfE (XX) in terms of intake $\left(I_{X}\right)$, apparently digested $\left(d_{X}\right)$ and apparently digested in the stomachs $\left(\mathrm{d}_{\mathrm{x} . \mathrm{S}}\right)$.

Similar as in Experiment I, the energetic efficiency of the synthesis of bacterial $\mathrm{N}$ was calculated. The results are shown in Table 6 . The results of the estimated proportions of feed $\mathrm{N}$ escaping degradation in the rumen are also shown in Table 6. 
Table 5. Intake $\left(\mathrm{I}_{\mathrm{X}}, \mathrm{kg} / \mathrm{day}\right)$, total apparent digestibility $\left(\mathrm{d}_{\mathrm{X}}, \%\right)$ and apparent digestibility in the forestomachs. as a percentage of $d_{X}\left(d_{X . S}\right)$ in Experiment II.

\begin{tabular}{|c|c|c|c|}
\hline & \multicolumn{3}{|l|}{ Treatment* } \\
\hline & II-A (2) & II-B (2) & II-C (2) \\
\hline DM from roughage $(\%)$ & $29 \pm 0.2$ & $56 \pm 0.1$ & $81 \pm 0.1$ \\
\hline XP from roughage $(\%)$ & $21 \pm 0.4$ & $48 \pm 1.0$ & $75 \pm 1.3$ \\
\hline $\mathbf{I}_{\mathrm{T}}$ & $8.5 \pm 0.01$ & $8.8 \pm 0.04$ & $9.2 \pm 0.02$ \\
\hline $\mathrm{I}_{\mathrm{O}}$ & $7.9 \pm 0.01$ & $8.2 \pm 0.06$ & $8.5 \pm 0.03$ \\
\hline$I_{X P}$ & $1.48 \pm 0.02$ & $1.41 \pm 0.01$ & $1.30 \pm 0.05$ \\
\hline$I_{X F}$ & $1.19 \pm 0.02$ & $1.82 \pm 0.02$ & $2.40 \pm 0.03$ \\
\hline $\mathbf{I}_{X X}$ & $4.29 \pm 0.03$ & $4.71 \pm 0.04$ & $4.55 \pm 0.05$ \\
\hline$\hat{d}_{\mathrm{T}}$ & $73 \pm 2.2$ & $74 \pm 0.6$ & $70 \pm 1.2$ \\
\hline $\mathrm{d}_{\mathrm{O}}$ & $75 \pm 2.1$ & $76 \pm 0.5$ & $72 \pm 0.8$ \\
\hline $\mathrm{d}_{\mathrm{XP}}$ & $68 \pm 2.6$ & $66 \pm 0.2$ & $63 \pm 1.4$ \\
\hline$d_{X F}$ & $51 \pm 2.0$ & $70 \pm 0.7$ & $71 \pm 0.7$ \\
\hline$d_{x x}$ & $83 \pm 2.3$ & $83 \pm 0.6$ & $72 \pm 0.8$ \\
\hline $\mathrm{d}_{\mathrm{T}, \mathrm{S}}$ & $42 \pm 4.7$ & $44 \pm 1.7$ & $42 \pm 0.8$ \\
\hline $\mathrm{d}_{\mathrm{O}, \mathrm{S}}$ & $55 \pm 3.0$ & $58 \pm 1.4$ & $61 \pm 0.3$ \\
\hline $\mathrm{d}_{\mathrm{XP}, \mathrm{S}}$ & $-7 \pm 12.3$ & $-15 \pm 2.1$ & $-32 \pm 1.6$ \\
\hline $\mathrm{d}_{\mathrm{XF}, \mathrm{S}}$ & $97 \pm 0.2$ & $90 \pm 1.6$ & $99 \pm 1.4$ \\
\hline $\mathrm{d}_{\mathrm{XX} . \mathrm{S}}$ & $73 \pm 1.8$ & $75 \pm 2.7$ & $79 \pm 3.7$ \\
\hline
\end{tabular}

* In parenthesis number of animals.

Table 6. Efficiency of microbial protein synthesis and extent of degradation of feed $\mathrm{N}$ in Experiment II.

\begin{tabular}{llll}
\hline & \multicolumn{2}{c}{ Treatment } & \\
\cline { 2 - 3 } & II-A & II-B & II-C \\
$\begin{array}{l}(\mathrm{XF}+\mathrm{XX}) \text { disappeared } \\
(\mathrm{kg} / \mathrm{day})\end{array}$ & $3.6 \pm 0.26$ & $4.0 \pm 0.13$ & $4.1 \pm 0.01$ \\
$\begin{array}{l}\text { Microbial } \mathrm{N} \text { in } \\
\text { Duodenal content } \\
(\mathrm{g} / \text { day) }\end{array}$ & $139 \pm 6.5$ & $119 \pm 10.4$ & $116 \pm 20.0$ \\
$\begin{array}{c}\text { Micr. N/(XF }+\mathrm{XX}) \text { ferm. } \\
(\mathrm{g} / \mathrm{kg})\end{array}$ & $38 \pm 1.0$ & $30 \pm 3.6$ & $28 \pm 5.0$ \\
$\begin{array}{c}\text { Undegraded feed } \mathrm{N} \\
\left(\% \text { of } \mathrm{I}_{\mathrm{N}}\right)\end{array}$ & $24 \pm 10.3$ & $33 \pm 6.4$ & $39 \pm 7.8$ \\
\hline
\end{tabular}

The experiments in series III were grouped in 4 treatments with 2 to 5 animals per treatment. Treatments were a low roughage to concentrate ratio at a high level of feed intake (treatments $\mathrm{A} 1$ and $\mathrm{A} 2$ ), a high roughage to concentrate ratio at a medium level of feed intake (treatments B1, B2. B3, B4 and B5), a low roughage to concentrate ratio at a low level of feed intake (treatment $\mathrm{CI}$ and $\mathrm{C} 2$ ) and a high roughage to concentrate ratio at a low level of feed intake (treatment D1 and D2). 


\section{S. TAMMINGA}

Table 7. Intake $\left(I_{X}, \mathrm{~kg} /\right.$ day $)$, total apparent digestibility $\left(\mathrm{d}_{X}, \%\right)$ and apparent digestibility in the stomachs, as percentage of $d_{X}\left(d_{X, S}\right)$, in Experiment III.

\begin{tabular}{|c|c|c|c|c|}
\hline & \multicolumn{4}{|l|}{ Treatment* } \\
\hline & III-A (2) & III-B (5) & III-C (2) & III-D (2) \\
\hline DM from roughage (\%) & $40 \pm 6.6$ & $81 \pm 3.1$ & $42 \pm 0.30$ & $83 \pm 16.1$ \\
\hline $\mathrm{XP}$ from roughage $(\%)$ & $30 \pm 4.2$ & $77 \pm 4.0$ & $35 \pm 2.6$ & $82 \pm 18.4$ \\
\hline $\mathbf{I}_{\mathrm{T}}$ & $15.7 \pm 0.03$ & $7.9 \pm 0.53$ & $5.6 \pm 0.45$ & $3.8 \pm 1.30$ \\
\hline $\mathrm{I}_{\mathrm{O}}$ & $14.5 \pm 0.05$ & $7.1 \pm 0.20$ & $5.2 \pm 0.44$ & $3.5 \pm 1.20$ \\
\hline$I_{X P}$ & $2.61 \pm 0.10$ & $1.07 \pm 0.07$ & $0.96 \pm 0.01$ & $0.64 \pm 0.30$ \\
\hline $\mathrm{I}_{\mathrm{XF}}$ & $2.54 \pm 0.16$ & $2.01 \pm 0.15$ & $1.10 \pm 0.00$ & $0.98 \pm 0.29$ \\
\hline$I_{X x}$ & $8.81 \pm 0.09$ & $3.82 \pm 0.30$ & $2.91 \pm 0.43$ & $1.76 \pm 0.57$ \\
\hline $\mathrm{d}_{\mathrm{T}}$ & $73 \pm 0.4$ & $77 \pm 2.8$ & $77 \pm 1.8$ & $73 \pm 0.5$ \\
\hline$d_{0}$ & $74 \pm 0.4$ & $78 \pm 2.7$ & $80 \pm 1.6$ & $75 \pm 0.1$ \\
\hline $\mathrm{d}_{\mathrm{XP}}$ & $66 \pm 0.0$ & $67 \pm 3.0$ & $70 \pm 5.3$ & $66 \pm 4.7$ \\
\hline $\mathrm{d}_{\mathrm{XF}}$ & $62 \pm 0.8$ & $78 \pm 2.3$ & $74 \pm 3.7$ & $79 \pm 0.2$ \\
\hline$d_{x x}$ & $81 \pm 0.5$ & $83 \pm 3.4$ & $85 \pm 0.4$ & $77 \pm 1.2$ \\
\hline $\mathrm{d}_{\mathrm{T} . \mathrm{S}}$ & $43 \pm 1.1$ & $49 \pm 3.1$ & $47 \pm 4.3$ & $42 \pm 1.2$ \\
\hline $\mathrm{d}_{\mathrm{O}, \mathrm{S}}$ & $56 \pm 0.7$ & $62 \pm 2.6$ & $61 \pm 3.2$ & $60 \pm 1.1$ \\
\hline $\mathrm{d}_{\mathrm{XP} . \mathrm{S}}$ & $-20 \pm 5.7$ & $-28 \pm 7.2$ & $-3 \pm 19.1$ & $-19 \pm 14.1$ \\
\hline$d_{X F, S}$ & $97 \pm 2.7$ & $95 \pm 2.0$ & $95 \pm 4.0$ & $93 \pm 0.7$ \\
\hline$d_{X X . S}$ & $79 \pm 1.3$ & $77 \pm 1.7$ & $75 \pm 1.5$ & $75 \pm 1.9$ \\
\hline
\end{tabular}

* In parenthesis number of animals.

Table 8. Efficiency of microbial protein synthesis and extent of degradation of feed $\mathrm{N}$ in Experiment III.

\begin{tabular}{lllll}
\hline & \multicolumn{2}{c}{ Treatment } & & \\
\cline { 2 - 4 } & III-A & III-B & III-C & III-D \\
$\begin{array}{l}(\mathrm{XF}+\mathrm{XX}) \text { disappeared } \\
(\mathrm{kg} / \text { day) }\end{array}$ & $7.3 \pm 0.10$ & $4.0 \pm 0.32$ & $2.7 \pm 0.15$ & $1.8 \pm 0.58$ \\
$\begin{array}{l}\text { Microbial } \mathrm{N} \text { in } \\
\text { Duodenal content } \\
\quad(\mathrm{g} / \text { day })\end{array}$ & $261 \pm 37.4$ & $109 \pm 11.7$ & $69 \pm 22.6$ & $52 \pm 5.9$ \\
$\begin{array}{l}\text { Micr. } \mathrm{N}(\mathrm{XF}+\mathrm{XX}) \text { ferm. } \\
(\mathrm{g} / \mathrm{kg})\end{array}$ & $36 \pm 4.6$ & $27 \pm 1.4$ & $25 \pm 7.0$ & $32 \pm 6.9$ \\
$\begin{array}{l}\text { Undegraded feed } \mathrm{N} \\
\left(\% \text { of } \mathrm{I}_{\mathrm{N}}\right)\end{array}$ & $30 \pm 11.4$ & $30 \pm 5.2$ & $33 \pm 3.1$ & $26 \pm 18.2$ \\
\hline
\end{tabular}

Mean digestion results of the various treatments expressed in a similar way as for the Experiments I and II are shown in Table 7.

Similar as in Experiments I and II were the energetic efficiencies of bacterial protein synthesis in the forestomachs calculated. The results are shown in Table 8. In this table are also shown the estimated proportions of feed $\mathrm{N}$ escaping degradation in the rumen. 


\section{Discussion}

\section{Digestion and site of digestion}

Increasing the proportion of long roughage in the diet tends to increase the total apparent digestion of crude fibre in all three series of experiments. It has often been observed that with concentrate-rich diets the degradation of cell wall constituents is inhibited, mainly as a result of a decreased ruminal $\mathrm{pH}$ with such diets. This inhibition may be caused by a specific inhibition of cellulose digesting strains of rumen bacteria (Stewart, 1977) or protozoa (Demeyer, 1980).

Our results show a tendency of a larger proportion of the apparantly digestible organic matter (ADOM) being digested in the stomachs with a larger proportion of long roughage in the diet. Little information has been published on the effect of changing the roughage/concentrates ratio on site of digestion. In experiments with sheep Chamberlain \& Thomas (1979) found that a gradual replacement of chopped hay by ground concentrates increased the total apparent digestibility of the dietary organic matter; the proportion of this ADOM digested in the stomachs was not clearly affected. The shift in site of digestion observed in our experiments must undoubtedly be related to changes in the rate of passage of different pools of feed particles. An increasing proportion of long roughage increases the passage rate of rumen fluid (Tamminga et al., 1978; Bull et al., 1979) and probably also of small feed particles. Passage rate of the long particles themselves is lower than of fluid and small feed particles (Hartnell \& Satter, 1979), so, replacing ground and pelleted concentrates by long roughage will probably increase the average retention time of feed particles in the forestomachs and thus enable the micro-organisms to degrade a larger part of the apparently digestible organic matter in the diet. From the results of the experiments reported here it remains inconclusive which part of the diet (cell wall constituents or cell contents) is affected most.

\section{Protein degradation and microbial protein synthesis}

The results on protein degradation show a large variation and it becomes therefore difficult to draw conclusions or to discover significant effects resulting from the shifts in level of intake or the ratio between long roughage and ground and pelleted concentrates. It should be realized, however, that the extent of protein degradation is calculated rather than measured. What remains after subtracting the total duodenal protein flow with the estimated endogenous contribution and the measured flow of microbial protein is assumed to be undegraded dietary protein. In this fraction, however, all inaccuracies of estimating or measuring the other fractions are accumulated.

In the experiments of Chamberlain \& Thomas (1979) referred to earlier of the 5 diets fed, only diets consisting of either pure roughage or diets consisting of over $85 \%$ ground concentrates, showed a decreased efficiency of microbial protein synthesis. In our experiments no such diets were fed, except in one case where the diet consisted of only $3 \mathrm{~kg}$ of long hay (treatment III-D2). In 
this case a rather high efficiency of microbial protein synthesis was found of $38 \mathrm{~g}$ of microbial $\mathrm{N}$ per $\mathrm{kg}$ carbohydrates fermented. As a result the proportion of feed $\mathrm{N}$ escaping degradation in this case became extremely low (8\%). Although not detectable, an analytical failure cannot be excluded. It seems therefore justified to conclude that if extreme roughage/concentrates ratios are avoided, the best way of estimating the contribution of microbial protein to the intestinal protein supply of ruminants is to use a constant factor related to some measure of dietary energy.

The average figure of $32.2 \mathrm{~g}$ of microbial $\mathrm{N}$ produced per $\mathrm{kg}$ of carbohydrates fermented agrees well with figures in literature. In new protein evaluating systems microbial protein synthesis is often related to digestible organic matter (DOM). From our results an average value of $132 \mathrm{~g}$ of microbial crude protein per $\mathrm{kg}$ DOM was calculated, which agrees very well with the values used in the different new protein evaluating systems for ruminants (Verite et al., 1979).

Extent of degradation of dietary protein in ruminant diets results from the rate of degradation and the rate of passage of both the protein in the roughage part of the diet and the protein in the concentrate part. Rate of passage of long roughage is much slower than that of ground and pelleted concentrates. The rate of passage of small particles may even be increased by the inclusion of long roughage in the diet, because the latter stimulates salivary production and the rate of passage of fluid (Tamminga et al., 1978). Part of the small particles will be suspended in the fluid and an increased outflow rate of fluid may therefore also increase the outflow rate of the small particles suspended in it. Rate of degradation also differs between long roughage and concentrates, and this is probably also true for protein in both dietary ingredients. Besides rate of degradation of protein in one part of the diet, for instance the concentrate part may be influenced by the presence of the other part. It was found in sheep (Ganev et al., 1979) that the rate of degradation of protein supplements in sheep fed a roughage-based diet was higher than in sheep fed a concentratebased diet. Because of all these interactions it becomes difficult if not impossible to give a reliable prediction of the extent of degradation of dietary protein in the forestomachs of ruminants.

Our results show that if mixed diets, consisting of long roughages and ground concentrates are fed, with no special measures taken to alter protein degradation, some $30 \%$ of the dietary protein escapes microbial degradation in the forestomachs. This figure agrees well with the figures proposed by Kaufmann (1979). That does however, not exclude the possibility of altering the extent of degradation either by increasing the rate of passage, or by decreasing the rate of degradation.

\section{References}

Ash. R. W.. 1962. Gastro-intestinal re-entrant cannulae for studies of digestion in sheep. Anim. Prod. 4: 309-312. 


\section{ROUGHAGE/CONCENTRATE RATIO AND N IN COW'S SMALL INTESTINE}

Bull, L. S.. W. V. Rumpler, T. F. Sweeney \& R. A. Zinn, 1979. Influences of ruminal turnover on site and extent of digestion. Fedn Proc. 38: 2713-2719.

Chamberlain. D. G. \& P. C. Thomas. 1979. Ruminal nitrogen metabolism and the passage of amino acids to the duodenum in sheep receiving diets containing hay and concentrates in various proportions. J. Sci. Fd Agric. 30: 677-686.

Demeyer, D.. 1980. Rumen microbes and the utilisation of cellulose wastes in ruminant feeding. OECD Seminar on production and protection of food, Uppsala, September 1980.

Ganev, G.. E. R. Orskov \& R. Smart, 1979. The effect of roughage or concentrate feeding and rumen retention time on total degradation of protein in the rumen. J. agric. Sci. Camb. 93: 651656.

Hartnell, G. F. \& L. D. Satter, 1979. Determination of rumen fill, retention time and ruminal turnover rates of ingesta at different stages of lactation in dairy cattle. J. Anim. Sci. 48: 381-392.

Hogan, J. P. \& A. T. Phillipson, 1960. The rates of flow of digesta and their removal along the digestive tract of the sheep. Br. J. Nutr. 14: 147-155.

Honing, Y. van der. 1975. Intake and utilisation of energy rations with pelleted forages by dairy cows. Thesis, Agricultural University, Wageningen.

Kaufmann, W.. 1979. Zur Eiweissverdauung bei Wiederkäuern im Hinblick aur die faktorielle Berechnung des Eiweisbedarfs. Z. Tierphysiol. Tierernährng u. Futtermittelkde 42: 326-333.

Kaufmann. W. and Hagemeister, H., 1976. Zum Einfluss der Behandlung von Protein mit Formaldehyd auf die bakterielle Proteinsynthese und die Abbaurate von Protein in die Vormägen von Milchkühen sowie auf die Verdaulichkeit des Proteins im Darm. Kiel. Milchw: ForschBer. 28: $335-346$.

Klooster, A. Th. van 't \& P. A. M. Rogers. 1970. The use of Cr-EDTA as an inert reference substance to measure the volume in and rate of flow of fluid and metabolites out of the reticulorumen of cows. Neth. J. vet. Sci. 3: 115-128.

Mason, V. C. \& S. Bech Anderson, 1976. The estimation of 2,6 diaminopimelic acid in digesta and faeces using acid ninhydrin reagent. $Z$. Tierphysiol. Tierernährng u. Futtermittelkde 36: 221-224.

Meyer, R. M.. E. E. Bartley, C. W. Deyoe \& V. F. Colenbrander, 1967. Feed Processing. 1, Ration effects on rumen microbial protein synthesis and amino acid composition. J. Dairy Sci. 50: 1327-1332.

Stewart, C. S.. 1977. Factors affecting the cellulolytic activity of rumen contents. Appl. environm. Microbiol. 33: 497-502.

Tamminga, S., 1979. Relation between different carbohydrates and microbial synthesis of protein. Report IVVO No 130.

Tamminga, S.. G. Dikstaal \& C. J. van der Koelen, 1973. A semi-automatic device for measuring the duodenal flow in adult cows. Report IVVO No 61.

Tamminga, S., A. M. van Vuuren \& C. J. van der Koelen, 1978. De betekenis van de fermentatie in de voormagen van herkauwers. Landbouwk. Tijdschr. 90: 197-203.

Uden, P. 1981. The effect of intake and proportion of concentrate on the digestibility and passage of feeds in dairy cows. 32nd Ann. Meeting EAAP (Zagreb, September 1981).

Verité, R., M. Journet \& R. Jarrige, 1979. A new system for the protein feeding of ruminants. The PDI system. Livestock Prod. Sci. 6: 349-367. 